\title{
Comparison between Destructive and Nondestructive Dynamic Tests in the Presence of Different Ions as the Curing Solution
}

Mohammad Hossein Eftekhar ${ }^{1}$, Tara HajiBabaie ${ }^{2 *}$, Mohammad Shekarchi Zadeh ${ }^{3}$ and Amin T Vahdat ${ }^{4}$

${ }^{1}$ Technical manager, Construction Materials Institute, University of Tehran, Iran

${ }^{2}$ Research Assistant, Construction Materials Institute, University of Tehran, Iran

${ }^{3}$ Professor and Director of Construction Materials Institute, University of Tehran, Iran

${ }^{4}$ Managing Consultant at IBM, Ames, USA

Submission: March 5, 2018; Published: June 06, 2018

*Corresponding author: Tara HajiBabaee, Master of Science in Civil Engineering, Kharazmi University, Tehran, Iran, Email: tara.hajibabaee@gmail.com

\begin{abstract}
In a chloride containing environment, concrete permeability is an important parameter affecting the service life of concrete structures. One of the methods to estimate corrosion rates of concrete is the Electrical Resistivity (ER) test. Two-point measurement techniques have been developed for calculating the ER of models. In this research, four different mixtures have been used in order to compare the destructive and nondestructive tests in the presence of different ions; for this purpose, after curing the samples to the age of 7 days in water, the samples were exposed to different ions until the age of 28 days. The ER and compressive strength of the samples were compared at the ages of 14 and 28 days. The results show that existence of different ions have great effects on ER value.
\end{abstract}

Keywords: Electrical resistivity; Compressive strength; Chloride; Sulfate; Carbonate; Sodium hydroxide ions

\section{Introduction}

Corrosion is one of the main causes of the deterioration of reinforced concrete structures. This causes costly repairs and sometimes leads to reconstruction and rehabilitation of the damaged structures. Existence of chloride in pore solution and near the bar accelerates the dioxide reactions of bars [1]. The Electrical Resistivity (ER) is a non-destructive testing method. The corrosion rate of reinforcement and the resistivity of concrete are related. One of the rate-controlling factors is ion transport between anodes and cathodes on the steel surface [2]. Simplifying Bazant's model [3], the resistivity and corrosion rates are inversed [4,5], although this relationship may be different with concrete composition [6-8]. Within a given structure, areas with low resistivity will be attacked with a relatively high corrosion rate.

This test enables the evaluation (without estimation) of the strength and the durability of the concrete in aggressive environments [9], especially in marine regions like the Persian Gulf. The ER is one of the durability indexes before the beginning of the corrosion and also one of the factors that determines the rate of the corrosion caused by carbonation or chloride ions in the concrete. Recently, many studies are working on effect of different additives and environmental effects on the destructive and nondestructive dynamic tests of concrete and asphalt pavement [9-11]. In fact, the ER is an intrinsic property that quantifies how strongly a given material opposes the flow of electric current in which this property is affected by an external electric field. In some of the references [12], some amounts are listed as the specific ER of the concrete and the probability of the reinforcement corrosion.

The ER of the concrete is one of the inherent and independent characteristics that is affected by some different factors such as the Water to Cement ratio (W/C), paste structure, amount of moisture, temperature, chemical composition of the cement, cement content and the mineral and chemical admixtures [13-17]. Furthermore, the ER may be used as a parameter for controlling the quality of concrete instead of compressive strength tests [18]. Since this test is nondestructive, it can be performed for in-situ controls [19]. By using this test for Quality Control of concrete, some errors that might show during the determining compressive strength can be removed from results. ER method is a fast, easy, and inexpensive, nondestructive measurement technique, which can be used for repetitive quality control of concrete and for the monitoring of structures. 


\section{Civil Engineering Research Journal}

The results for the chemical analysis of Persian Gulf water are presented in Table 1 [20]. Because of the existence of destructive ions, such as sulfate and chloride, the Persian Gulf is an aggressive environment for the reinforced concrete structures. When the structure has been evaluated for estimating probable damage it should be noted that every ion may cause different damage on the concrete reinforcement structure. This study shows' that $\mathrm{NaCl}, \mathrm{Na}_{2} \mathrm{SO}_{4}, \mathrm{NaOH}$, and $\mathrm{Na}_{2} \mathrm{CO}_{3}$ as electrolytes, have different effects on concrete ER and compressive strength, which are two common tests in assessment.

Table 1: Chemical analysis of Persian Gulf water.

\begin{tabular}{|c|c|}
\hline Ions & Persian Gulf (ppm) \\
\hline $\mathrm{So}_{4}^{2-}$ & 2720 \\
\hline $\mathrm{Na}^{+}$ & 12400 \\
\hline $\mathrm{Cl}^{-}$ & 21450 \\
\hline $\mathrm{Mg}^{2+}$ & 1460 \\
\hline $\mathrm{K}^{+}$ & 450 \\
\hline $\mathrm{Ca}^{2+}$ & 430 \\
\hline
\end{tabular}

\section{Materials and Experimental Methods}

\section{Mix design}

3In this study, four series of mixtures with $\mathrm{W} / \mathrm{C}, 0.4,0.45$, 0.5 , and 0.6 , were made and tested. The summary of mixtures are given in Table 2. In this study, Type II Portland cement and coarse crushed aggregate with a maximum size of $19 \mathrm{~mm}$ and natural fine aggregate were used. To achieve optimum performance, the naphthalene-based superplasticizer was used. The chemical composition of cement is presented in Table 3. The gradation of mid- and coarse aggregate is given in Table 4 . The tests were done at the Construction Materials Institute at the University of Tehran.

Table 2: Mix designs*.

\begin{tabular}{|c|c|c|c|c|c|}
\hline Mix Designs Code & Cement $\left(\mathbf{K g} / \mathbf{m}^{3}\right)$ & W/C & $\begin{array}{c}\text { Fine Aggregates } \\
\left(\mathbf{K g} / \mathbf{m}^{3}\right)\end{array}$ & $\begin{array}{c}\text { Coarse Crushed } \\
\text { Aggregate }\left(\mathbf{K g} / \mathbf{m}^{\mathbf{3}}\right)\end{array}$ & $\begin{array}{c}\text { Super Plasticizer } \\
\left(\mathbf{K g} / \mathbf{m}^{\mathbf{3}}\right)\end{array}$ \\
\hline Code 1 & 400 & 0.4 & 1093 & 710 & 4 \\
\hline Code 2 & 400 & 0.45 & 1081 & 702 & 3.2 \\
\hline Code 3 & 400 & 0.5 & 1069 & 694 & 2.4 \\
\hline Code 4 & 400 & 0.6 & 1044 & 678 & 0 \\
\hline
\end{tabular}

*The aggregates are in Saturated Surfaces Dry (SSD) condition.

Table 3: Chemical analysis of Portland cement.

\begin{tabular}{|c|c|}
\hline Composition (\%) & Portland Cement Type II \\
\hline Loss on ignition & 2.2 \\
\hline $\mathrm{SiO}_{2}$ & 20.9 \\
\hline $\mathrm{Al}_{2} \mathrm{O}_{3}$ & 3.9 \\
\hline $\mathrm{Fe}_{2} \mathrm{O}_{3}$ & 3.6 \\
\hline $\mathrm{CaO}$ & 65.2 \\
\hline $\mathrm{MgO}$ & 2.9 \\
\hline $\mathrm{SO}_{4}$ & 0.9 \\
\hline $\mathrm{K}_{2} \mathrm{O}$ & 0.6 \\
\hline $\mathrm{Na}_{2} \mathrm{O}$ & 0.1 \\
\hline
\end{tabular}

Table 4: Aggregate gradation.

\begin{tabular}{|c|c|c|c|c|c|c|c|c|c|c|c|}
\hline Sieve's size (mm) & 25 & 19 & 12.5 & 9.5 & 4.75 & 2.36 & 1.18 & 0.6 & 0.3 & 0.150 & 0.75 \\
\hline Sand & 100 & 100 & 100 & 100 & 86 & 56 & 35 & 25 & 14.3 & 3.4 & 1.7 \\
\hline Mid aggregate & 100 & 100 & 100 & 86 & 15.5 & 4.6 & 0 & 0 & 0 & 0 & 0 \\
\hline Coarse aggregate & 100 & 96 & 33 & 4 & 0.1 & 0.1 & 0 & 0 & 0 & 0 & 0 \\
\hline
\end{tabular}




\section{Procedure of tests}

The test samples were cylinders with a height and diameter of $70 \mathrm{~mm}$. Each test sample was kept for 28 days in the intended solutions with a $24{ }^{\circ} \mathrm{C}$ temperature; their amounts of ER were measured at the ages of 14 and 28 days.

Samples were made according to ASTM C192, and were cured in the standard condition according to ASTM C31. Samples were cured in a saturated calcium hydroxide water bath for 7 days. For filling the water pore solution with desired ions, the samples were dried in an oven at a temperature of $110^{\circ} \mathrm{C}$ during 3 days, then stored in a desiccator with a vacuum pump during 7 days, at a temperature of $25{ }^{\circ} \mathrm{C}$. After this stage, 48 samples were placed in the $\mathrm{NaCl}, \mathrm{Na}_{2} \mathrm{SO}_{4}, \mathrm{NaOH}$, and $\mathrm{Na}_{2} \mathrm{CO}_{3}$ solutions. Also, 12 samples were kept in a saturated calcium hydroxide water bath as control samples, at a temperature of $24{ }^{\circ} \mathrm{C}$ for all environments.

\section{Properties of solutions}

Durability of concrete structures in the marine space and sewage environments is very important. Most of the harmful ions of these environments for concrete are Chloride $\left(\mathrm{Cl}^{-}\right)$, Carbonate $\left(\mathrm{CO}_{3}{ }^{2-}\right)$ and Sulfate $\left(\mathrm{SO}_{4}{ }^{2-}\right)$. Also, the alkaline environment is very effective in sustainability of structures. For these reasons, in this research four solutions were used as hydro-environments for concrete storage. Table 5 shows the concentration of dominant ions in each solution.

Table 5: The solutions used in the test.

\begin{tabular}{|c|c|c|c|}
\hline \multirow{2}{*}{ Code* $^{*} \mathrm{~B}$} & Solution & Ion & ppm \\
\hline \multirow{2}{*}{$\mathrm{N}$} & $\mathrm{NaOH}$ & $\mathrm{Na}^{+}$ & 22990 \\
\cline { 3 - 4 } & & $\mathrm{OH}$ & 17000 \\
\hline \multirow{2}{*}{$\mathrm{C}$} & $\mathrm{NaCl}$ & $\mathrm{Na}^{+}$ & 22990 \\
\cline { 3 - 4 } & & $\mathrm{Cl}^{-}$ & 35450 \\
\hline \multirow{2}{*}{$\mathrm{N}$} & $\mathrm{Na}_{2} \mathrm{SO}_{4}$ & $\mathrm{Na}^{+}$ & 45980 \\
\cline { 3 - 4 } & & $\mathrm{SO}_{4}^{2-}$ & 192280 \\
\hline \multirow{2}{*}{$\mathrm{E}$} & $\mathrm{Na}_{2} \mathrm{CO}_{3}$ & $\mathrm{Na}^{+}$ & 45980 \\
\cline { 3 - 4 } & & $\mathrm{CO}_{3}^{2-}$ & 84030 \\
\hline
\end{tabular}

*The "A" samples are samples that have been placed in a saturated calcium hydroxide water bath.

The two point method has been used for measuring the amount of ER. Figure 1 shows the two point method. For each specimen, two samples were used for measuring the amount of ER. After determining the ER, it is obtained by Equation 1 [20].

$$
\rho=R \frac{A}{L}(1)
$$

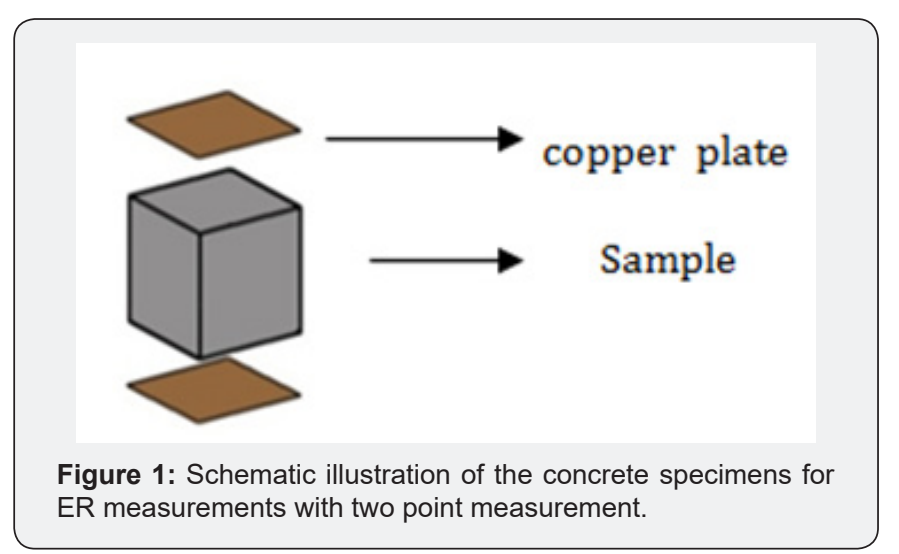

\section{Results and Discussion}

\section{The Effect of Ions on the ER}

The results are shown in Figure 2-11. According to the results, it can be concluded that the age of samples, W/C, and different electrolytes have an obvious effect on the ER. The W/C is one of the most important parameters on the concrete strength and durability, because this ratio has a very important role on the porous volume of the cement paste. For this reason, the ER of the concrete is affected by this ratio. According to research [21,22], it can be found that, by decreasing the $\mathrm{W} / \mathrm{C}$, the concrete strength is increased. According to Figure 2, this result is observed for the concrete with different $\mathrm{W} / \mathrm{C}$, and in the presence of different electrolytes. On the other hand, with increasing the age and the W/C, ER increases are visible in Figure 3-7.

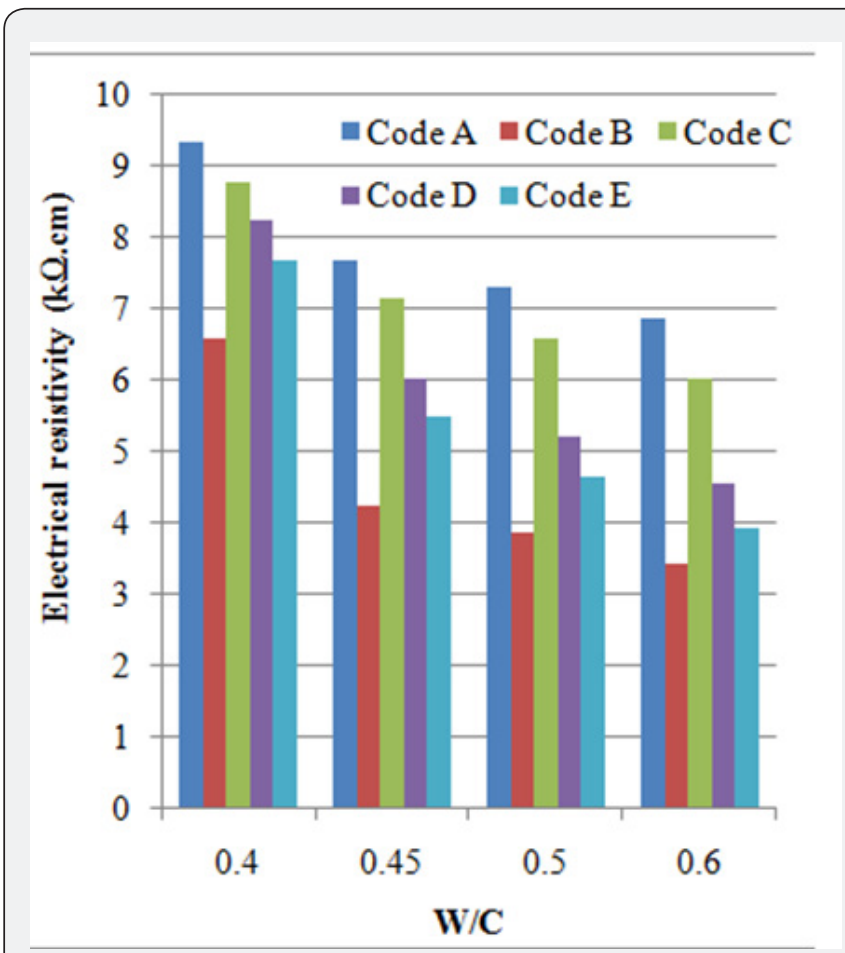

Figure 2: The diagram of the ER with changing W/C in the age of 28 days. 


\section{Civil Engineering Research Journal}

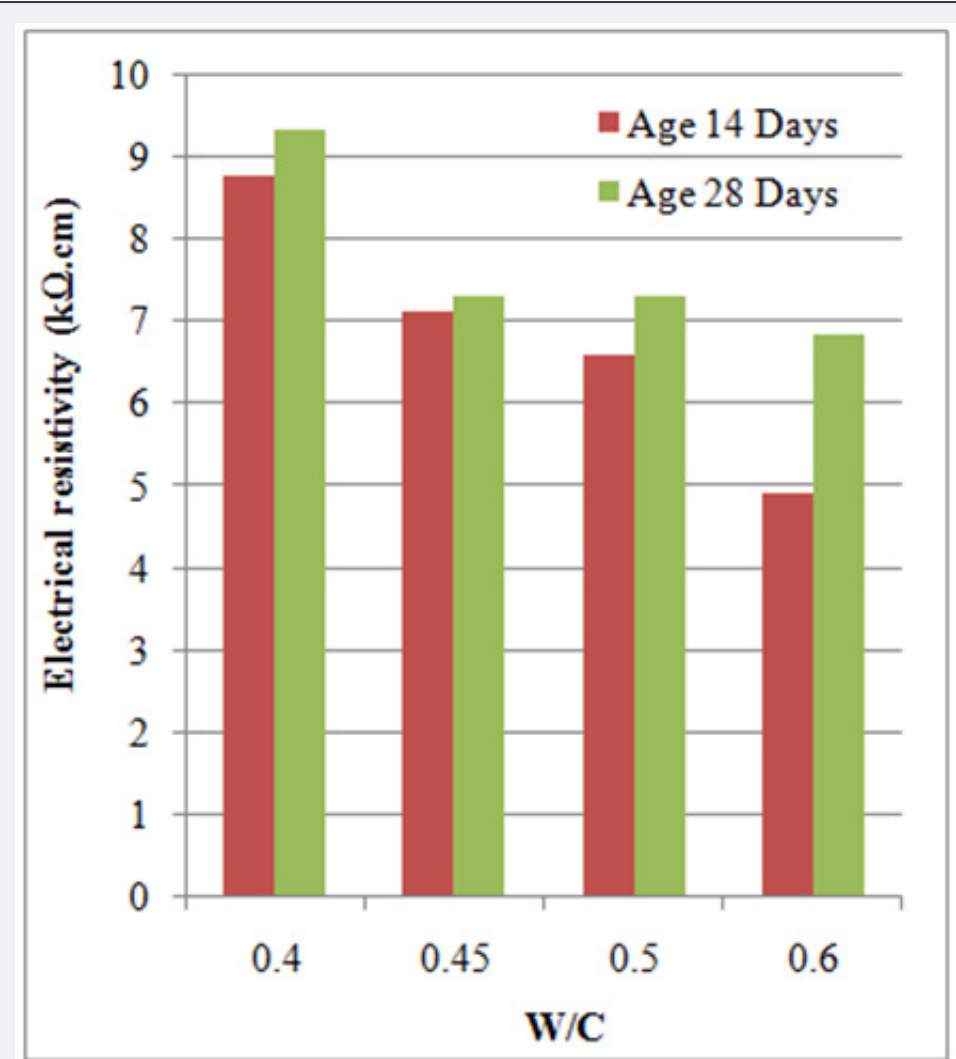

Figure 3: The diagram of the ER with changing age of the samples (code A).

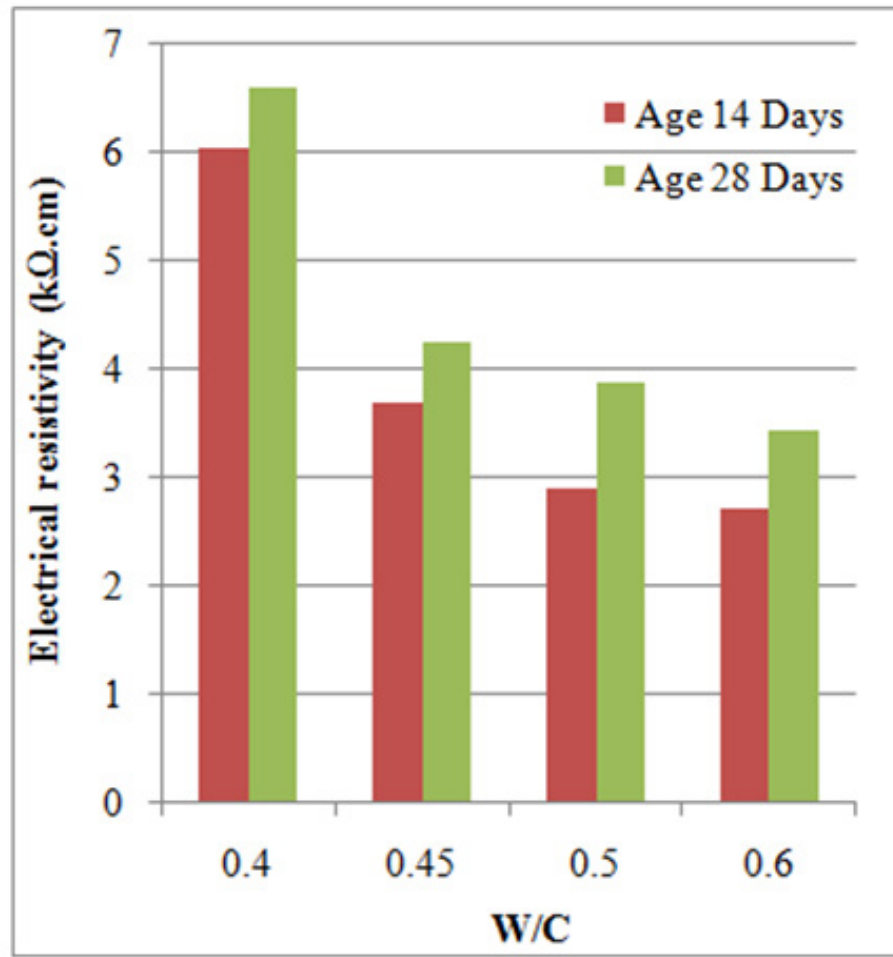

Figure 4: The diagram of the ER with changing age of the samples (code B). 


\section{Civil Engineering Research Journal}

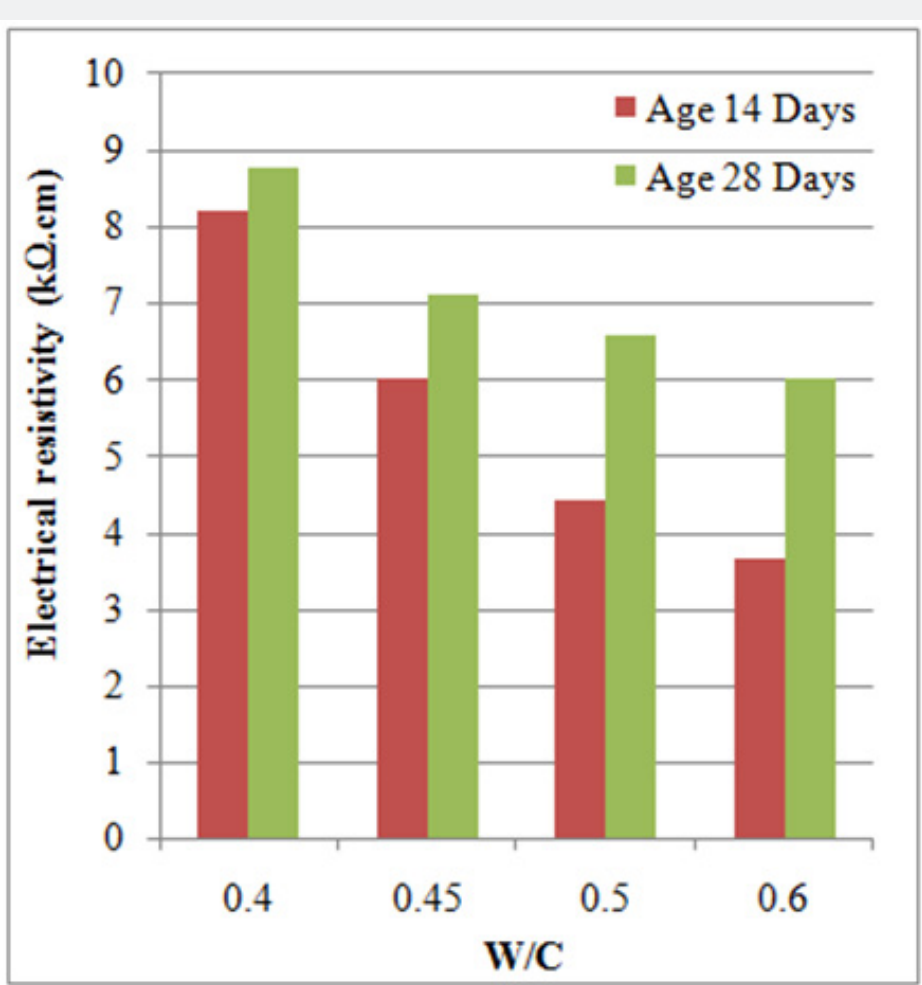

Figure 5: The diagram of the ER with changing age of the samples (code C).

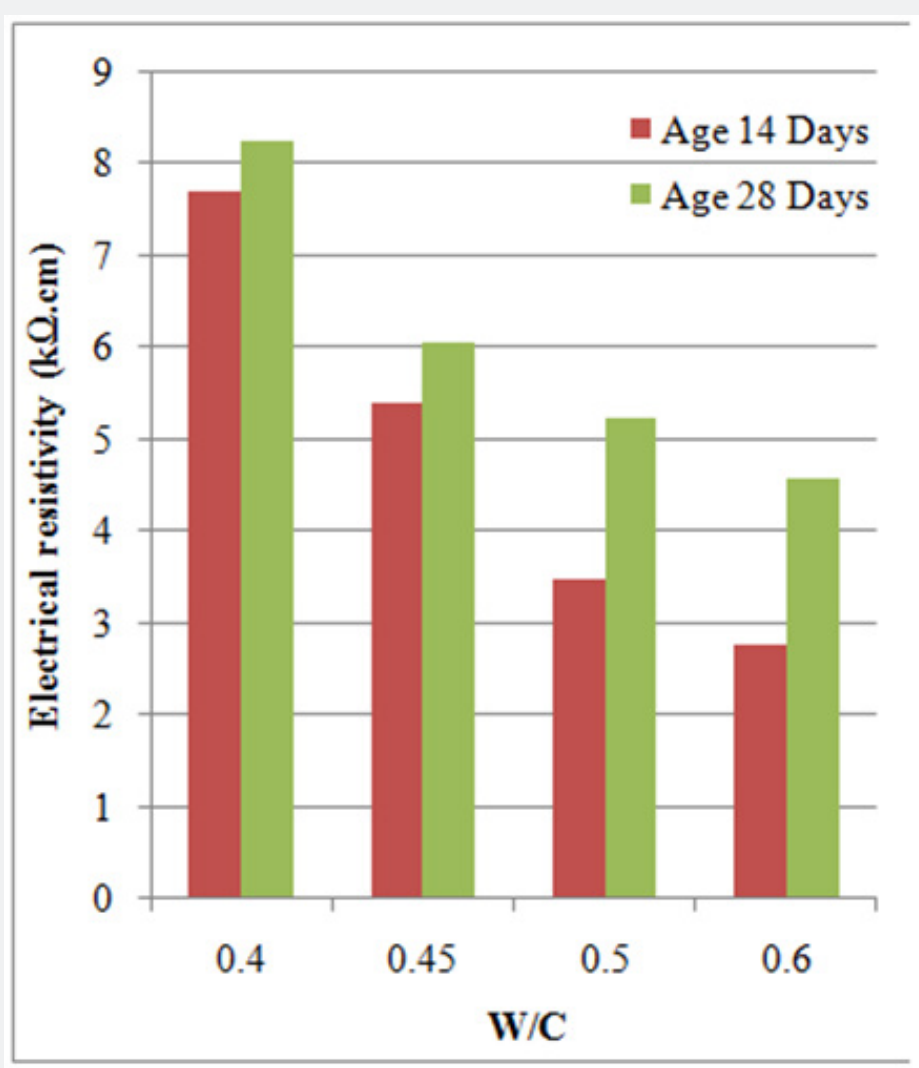

Figure 6: The diagram of the ER with changing age of the samples (code D). 


\section{Civil Engineering Research Journal}

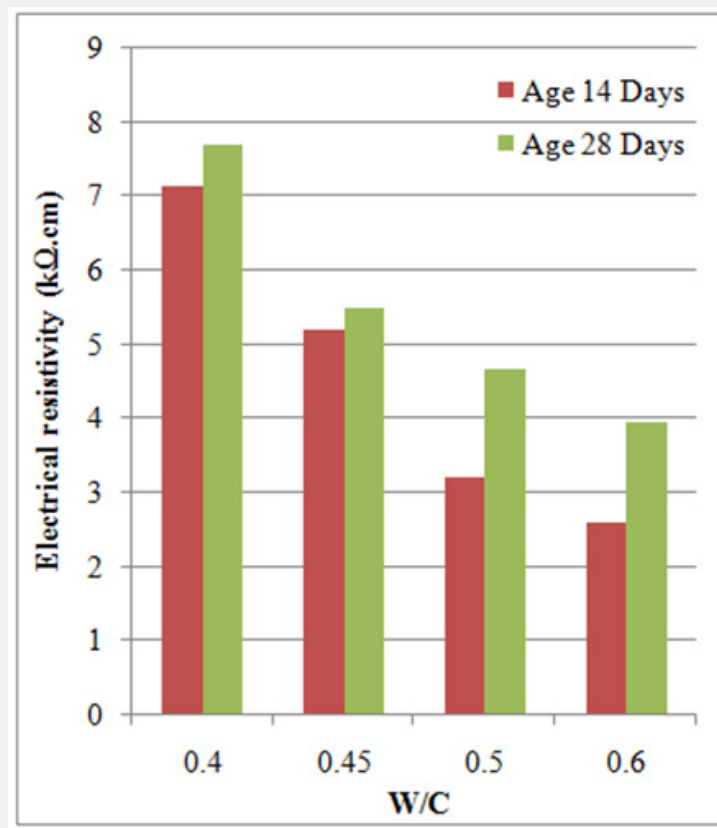

Figure 7: The diagram of the ER with changing age of the samples (code E).

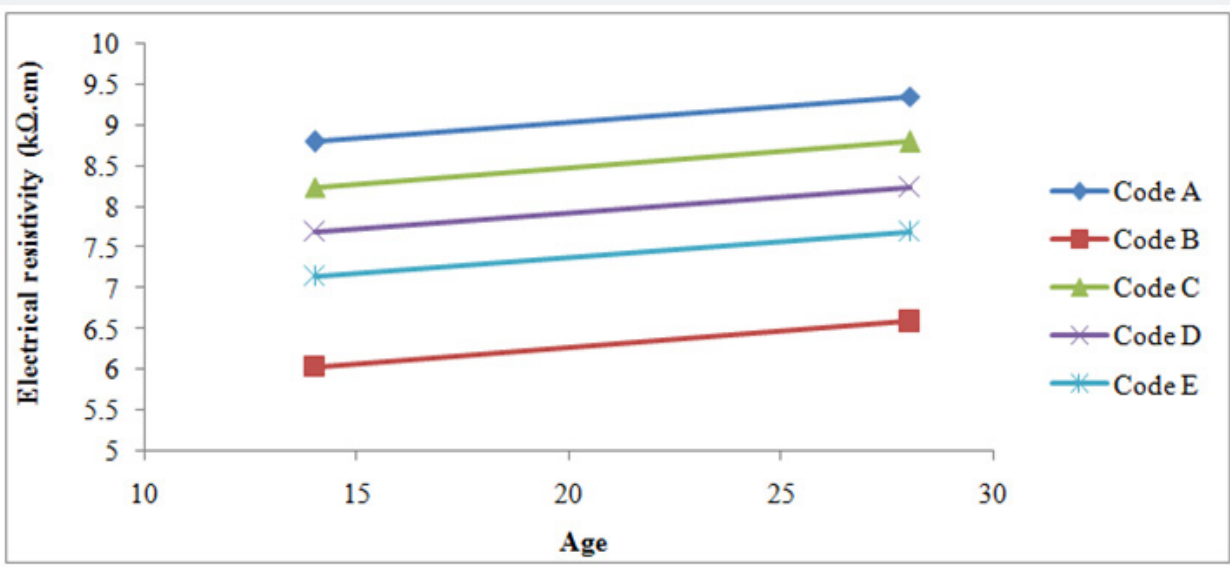

Figure 8: The diagram of the ER with changing age of the samples (code E).

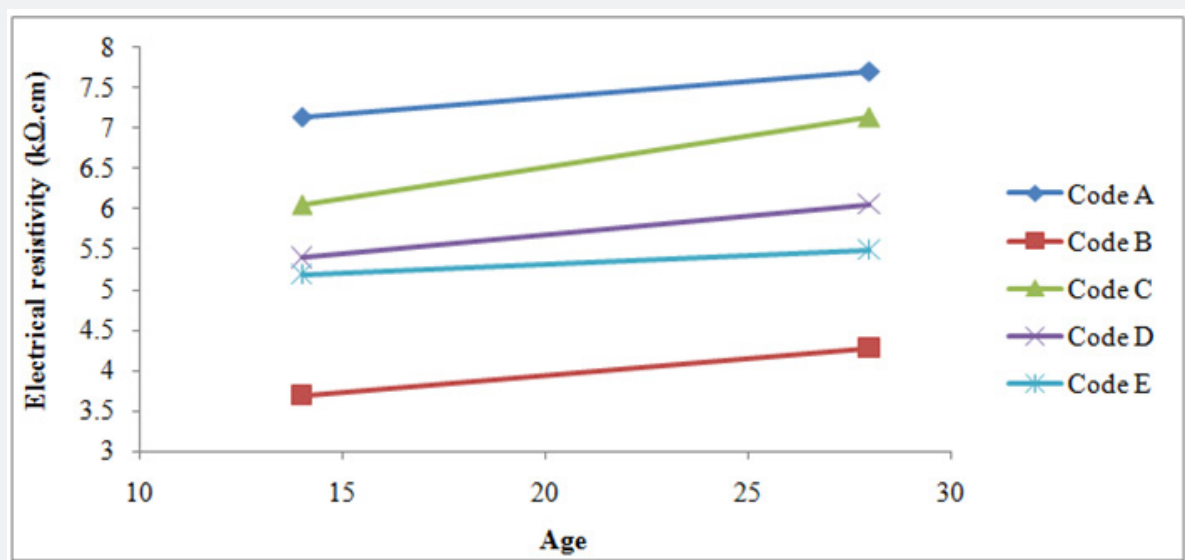

Figure 9: Comparing the ER of the sample with the W/C of 0.45 in the presence of different electrolytes. 


\section{Civil Engineering Research Journal}

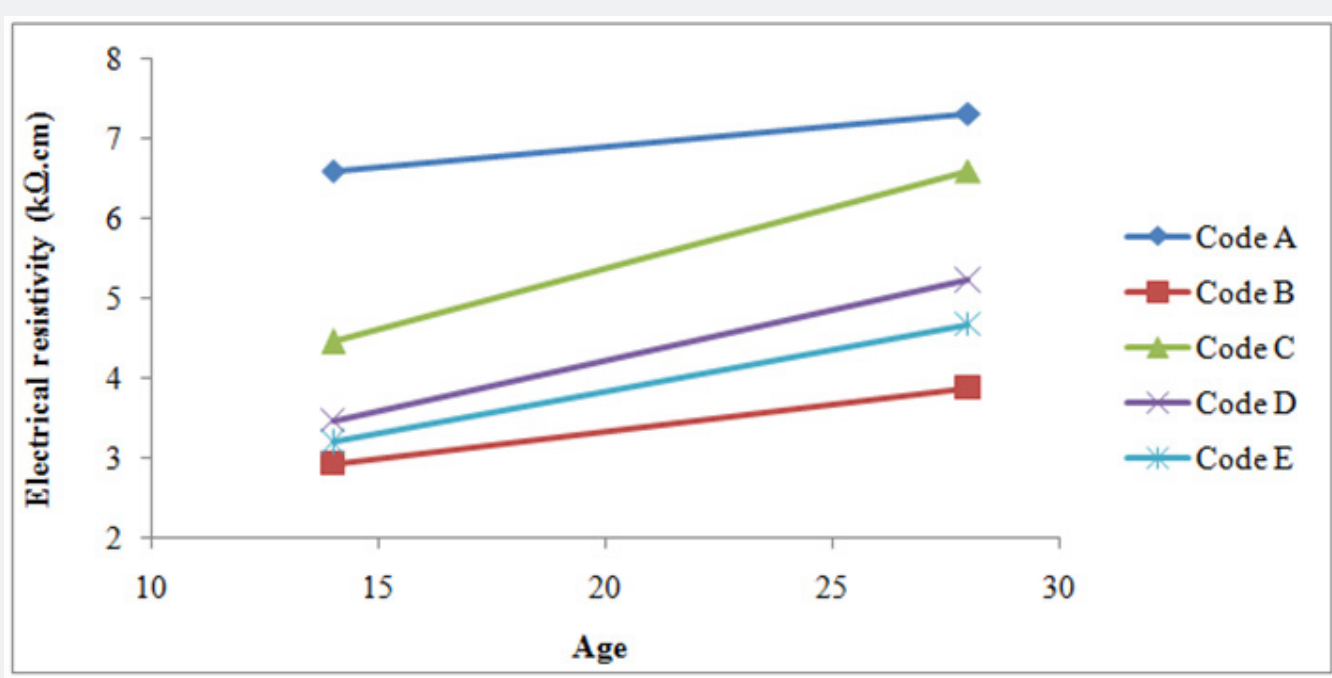

Figure 10: Comparing the ER of the sample with the W/C of 0.5 in the presence of different electrolytes.

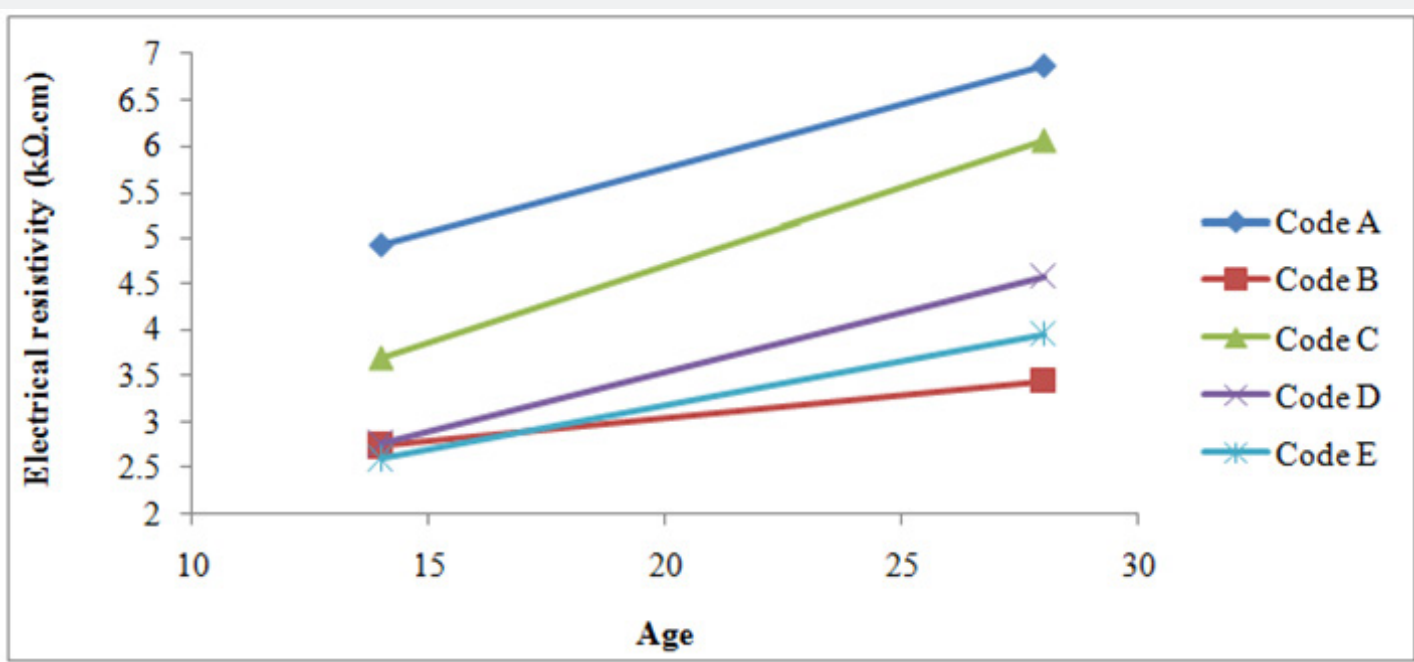

Figure 11: Comparing the ER of the sample with the W/C of 0.6 in the presence of different electrolytes.

According to Figure 3-7, it can be seen that the W/C has an effect on the rate of ER increasing for each code. For reference samples with $\mathrm{W} / \mathrm{C}$ equal to 0.4 , ER is 3.5 times greater than that of samples with $\mathrm{W} / \mathrm{C}$ equal 0.6 . This subject can be seen in other environments. We should notice that the development of ER value within age is different in various environments and W/C. In some codes, the rate of difference is 4 times more. Concrete with lower $\mathrm{W} / \mathrm{C}$ has less volume capillary pores, especially in early ages. Also, due to the presence of different ions in a different environment, rate of hydration is changed.

\section{Effect of ions in the ER after 14 and 28 days}

In Figure 8-11, changes of ER in different environments were shown (when w/c is the same).

The results of Figure 8-11 show that the reference samples have the highest ER when compared with other samples, which means the ER decreases in the presence of different ions. For instance, code B (Alkaline environment) has the minimum ER between other codes where W/C is 0.4 ; the ER decreases about $70 \%$ when compared with reference samples and this reaches $50 \%$ for $\mathrm{W} / \mathrm{C}$ equal to 0.6 . The chloride ion has the minimum effect on the decrease in the ER when compared with other samples. For W/C equal to 0.6 , the ER decreases $12 \%$ when compared with the reference sample and it goes to $5 \%$ for W/C equal to 0.4. All the diagrams show that the ER of the D and $E$ samples (Sulfated and Carbonated environments) are almost the same and the results are close to each other.

\section{The Effect of Ions on the compressive strength of 28 day Samples}

The compressive strength is affected by different factors such as W/C, curing methods, and many other characteristics [23]. Based on previous research, there are some papers that showed 
the effect of ions on the compressive strength, but none of them compared the effect of different ions [24]. According to Figure 12, it can be found that the code B samples (Alkaline environment) have more compressive strength, but according to part 3.4, this code has the least ER. This contrast shows that the [OH]- ion has the most electric ion transport in the concrete. In other samples by decreasing the ER, compressive strength also decreases, but with a different rate such as the compressive strength of the $\mathrm{E}$ samples (Carbonated environments) is about $10 \%$ to $37 \%$ lower when compared with the $\mathrm{C}$ samples (Chloride environments). The results show a difference between permittivity of the chloride, sulfate, and carbonate ions. According to diagram 12, it can be found that the electron permittivity in the concrete for the $[\mathrm{OH}]^{;},[\mathrm{Cl}]^{;},\left[\mathrm{SO}_{4}\right]^{2-},\left[\mathrm{CO}_{3}\right]^{2-}$ ions decreases in order.

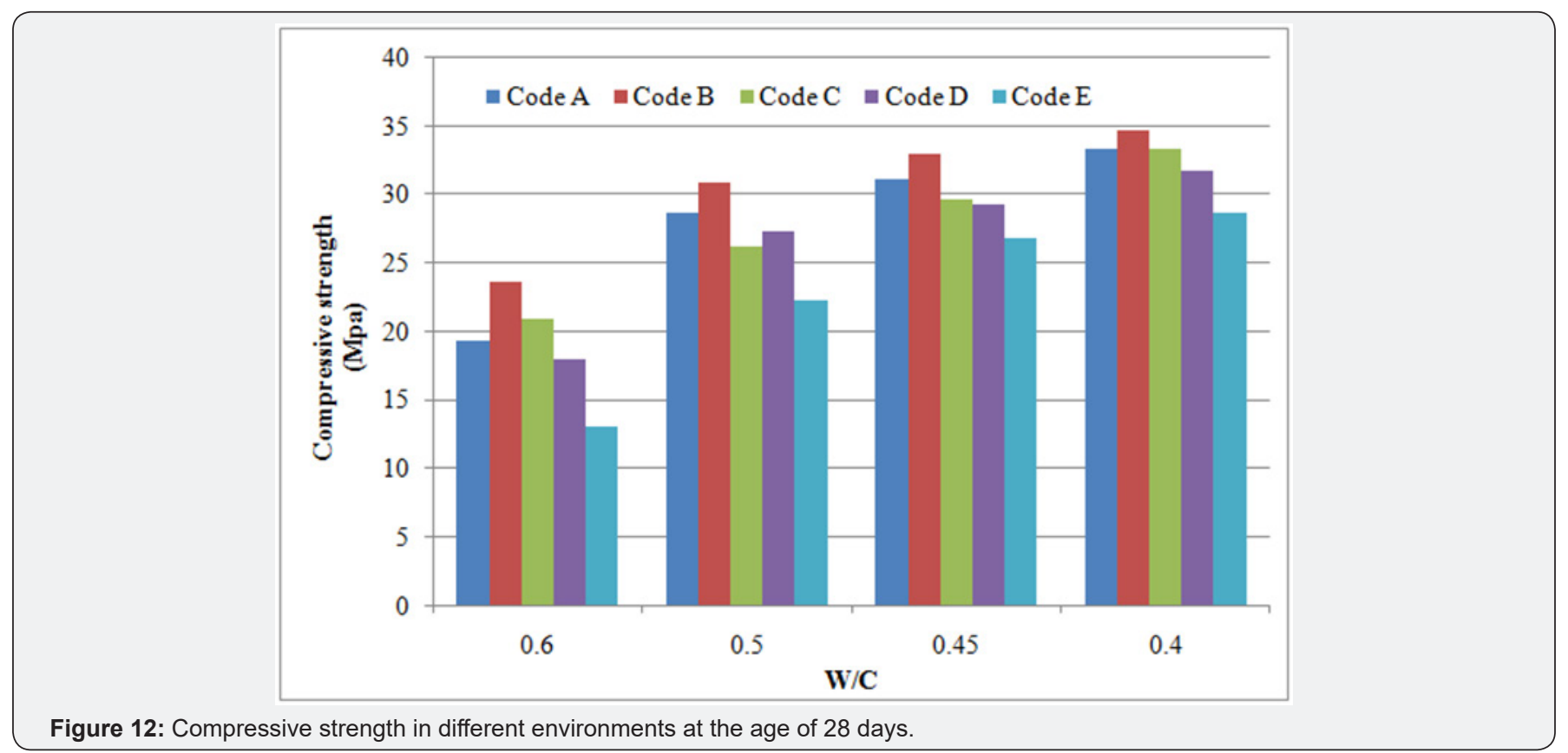

\section{Conclusion}

The simplest method for measuring the ER of the concrete structures is performing the site experiments; taking attention to this point is very important, since the structures show different ER in different marine, wastewater, alkaline, or experimental environments. This differences in the characteristics of the ions do not show the change between the concrete samples because of the amount of the dominant ion in the pores of the concrete.

a) The samples that are saturated in the $\mathrm{NaOH}$ solution have less ER when compared to other solutions.

b) When decreasing the water to cement ratio, the difference between ER of other samples decreases.

c) The samples that are placed in the sulfated and carbonated environments have the same ER.

d) The ER increase rate in time is different for various water to cement ratios and solutions.

e) The ER and compressive strength relation can be different in the presence of different ions and depends on the present ion permittivity. f) The $[\mathrm{OH}]^{-}$has the most permittivity and after that the permittivity decreases in order for $\left[\mathrm{Cl}^{-},\left[\mathrm{SO}_{4}\right]^{2-},\left[\mathrm{CO}_{3}\right]^{2-}\right.$ ions.

\section{References}

1. Shen W, Ceylan H, Gopalakrishnan K, Kim S, Nahvi A (2017) Sustainability Assessment of Alternative Snow-Removal Methods for Airport Apron Paved Surfaces (No. DOT/FAA/TC-17/34).

2. Schiessl P (1988) Corrosion of Steel in Concrete: Report of the Technical Committee 60 CSC, RILEM (the International Union of Testing and Research Laboratories for Materials and Structures). Chapman \& Hall.

3. Bazant ZP (1979) Physical model for steel corrosion in concrete sea structures--theory. Journal of the Structural Division, 105(6): 11371153 (ASCE 14651 Proceeding).

4. Alonso C, Andrade C, Gonzalez JA (1988) Relation between resistivity and corrosion rate of reinforcements in carbonated mortar made with several cement types. Cement and concrete research 18(5): 687-698.

5. Glass GK, Page CL, Short NR (1991) Factors affecting the corrosion rate of steel in carbonated mortars. Corrosion Science 32(12): 1283-1294.

6. Polder RB, Bamforth PB, Basheer M, Chapman-Andrews J, Cigna R (1994) Reinforcement corrosion and concrete resistivity-state of the art, laboratory and field results. In International Conference on Corrosion and Corrosion Protection of Steel in Concrete, pp. 571-580.

7. Fiore S, Polder RB, Cigna R (1996) Evaluation of the concrete corrosivity by means of resistivity measurements. Special PublicationRoyal Society of Chemistry 183: 273-282. 


\section{Civil Engineering Research Journal}

8. Anand P, Nahvi A, Ceylan H, Pyrialakou VD, Gkritza K (2017) Energy and Financial Viability of Hydronic Heated Pavement Systems (No. DOT/FAA/TC-17/47).

9. Andrade C (1993) Calculation of chloride diffusion coefficients in concrete from ionic migration measurements. Cement and concrete research 23(3): 724-742.

10. Alonso C, Andrade C, Gonzalez JA (1988) Relation between resistivity and corrosion rate of reinforcements in carbonated mortar made with several cement types. Cement and concrete research 18(5): 687-698.

11. Daghighi A, Nahvi A (2014) Effect of different additives on fatigue behavior of asphalt mixtures. Construction Materials and Structures, pp. 601-607.

12. Committee ACI (1989) 222, Report 222 R. Corrosion of Metals in Concrete.

13. Andrade C (2004) The limit of service life of concrete structures. (in Spanish) Encontro Nacional Betão Estrutural 2004, FEUP, Porto, p. $1-25$.

14. Haghiri S, Daghighi A, Moharramzadeh S (2018) Optimum coagulant forecasting by modeling jar test experiments using ANNs. Drinking Water Engineering and Science 11(1): 1-8.

15. Hunkeler F (1996) The resistivity of pore water solution-a decisive parameter of rebar corrosion and repair methods. Construction and Building Materials 10(5): 381-389.

16. Hope BB, Ip AK, Manning DG (1985) Corrosion and electrica impedance in concrete. Cement and concrete research 15(3): 525-534.

17. Daghighi A (2017) Harmful Algae Bloom Prediction Model for Western Lake Erie Using Stepwise Multiple Regression and Genetic Programming, Electronic Thesis.

18. Whiting DA, Nagi MA (2003) Electrical resistivity of concrete-a literature review. R\&D Serial, 2457.
19. Castellote M, Andrade C, Alonso MC (2002) Standardization, to reference of $25 \mathrm{C}$, of electrical resistivity for mortars and concretes in saturated or isolated conditions. Materials Journal 99(2): 119-128.

20. Andrade C (2005) Model for prediction of reinforced concrete service life based on electrical resistivity. Ibracon Structures and Materials Journal, 1(1).

21. Sengul 0, Gjørv OE (2008) Electrical resistivity measurements for quality control during concrete construction. ACI Materials Journal 105(6): 541-547.

22. Alizade R. The thesis for B.Sc. Degree, Investigating the Effect of the Type and the Duration of the Production Process on the Rate of the Chloride ion Penetration in the Persian Gulf Environment, Guiding Professor: Dr. Ghalibafian and Dr. Ramezanina, Khordad 1383.

23. Kaplan MF (1959) The effects of age and water/cement ratio upon the relation between ultrasonic pulse velocity and compressive strength of concrete. Magazine of Concrete Research, 11(32): 85-92.

24. Behnood A, Ziari H (2008) Effects of silica fume addition and water to cement ratio on the properties of high-strength concrete after exposure to high temperatures. Cement and Concrete Composites 30(2): 106-112.

25. Raheem AA, Soyingbe AA, Emenike AJ (2013) Effect of curing methods on density and compressive strength of concrete. International Journal of Applied Science and Technology, 3(4).

26. Mutitu DK, Karanja JK, Wachira JM (2014) Diffusivity of Chloride Ion in Mortar Cubes Made Using Ordinary Portland and Portland Pozzolana Cements.

27. Talal AB (2013) The impact of water content and ionic diffusion on the uniaxial compressive strength of shale. Egyptian Journal of Petroleum 22(2): 249-260.

\section{Your next submission with Juniper Publishers} will reach you the below assets

- Quality Editorial service

- Swift Peer Review

- Reprints availability

- E-prints Service

- Manuscript Podcast for convenient understanding

- Global attainment for your research

- Manuscript accessibility in different formats

(Pdf, E-pub, Full Text, Audio)

- Unceasing customer service

Track the below URL for one-step submission https://juniperpublishers.com/online-submission.php 